\title{
PENDAMPINGAN PENDIRIAN BANK SAMPAH DAN PELATIHAN OLAH SAMPAH MANDIRI BASIS MIKROBIAL DI PASAR JENGKOL TANGSEL
} Ni Made Sudri ${ }^{1)}$ Moh. Hardiyanto ${ }^{1)}$ Nunie Nurida ${ }^{1)}$, Daniel Sembiring ${ }^{1)}$

Program Studi Teknik Industri, Institut Teknologi Indonesia. Jl Raya Puspuptek, Serpong, Kota Tangerang Selatan E-mail : sudrimade@yahoo.co.id

\begin{abstract}
South Tangerang City Government immediately revitalized three traditional markets in its area to provide adequate buying and selling places and increase regional revenue from retribution. "Those three markets are Gintung Market in East Ciputat, Pamulang Market and Jengkol Setu Market. The problem of waste is a public complaint specifically in Jengkol Market because TPS has the market located adjacent to settlements and roadside ... The impact of the pile of garbage creates unpleasant odors and can become a source of disease, then it should be dealt with immediately. Solutions offered to resolve the problem by providing Waste Bank Ownership Assistance to function effectively to reduce waste piles at the TPS, and become UPT partners in managing environmental cleanliness through the management of organic microbial waste by making the market organic waste, as planting media products distributed by traders around the jengkol market, and the community or used alone for plants in the market environment so it is expected to be able to $t$ is an example of an Environmentally Friendly Market that is optimally and sustainably managed.
\end{abstract}

Keywords: Trash Bank, Market Trash, Microbial

\section{PENDAHULUAN}

Kota Tangerang Selatan terletak di bagian timur Provinsi Banten dan berada dalam posisi yang strategis, karena terletak pada poros wilayah Jabodetabek (JakartaBogor-Depok-Tangerang-Bekasi). Secara administratif terdiri dari 7 kecamatan, dan 54 kelurahan dengan luas wilayah $147,19 \mathrm{Km}^{2}$ atau $14.719 \mathrm{Ha}$.

Upaya mendukung program pembangunan Pemkot yang berwawasan lingkungan, maka salah satu program strategis Dinas Perindustrian dan Perdagangan, Pemkot Tangerang Selatan melakukan penataan dan renovasi pasar, serta mencanangkan bahwa di seluruh pasar harus dikelola secara ramah lingkungan antara lain dengan pendirian Bank Sampah. Sampah Pasar, khususnya sampah organik yang berpotensi mencemari lingkungan perlu dikelola dengan baik. Beragam sampah seperti plastik, daun, sayur busuk atau sampah organik dan anorganik bercampur menjadi satu dan menimbulkan kesan kumuh, becek dan bau tak sedap, dan membuat konsumen malas berbelanja ke pasar tradisional. Pasar ini memiliki luas bagunan $713,5 \mathrm{~m}^{2}$ di lahan seluas $1500 \mathrm{~m}^{2}$ dengan jumlah pedagang 51 orang, yang umumnya berdagang sayuran dan sembako.
Permasalahan yang ditemukan saat survei di lokasi, beberapa permasalahan yang ditemukan pada mitra, diantaranya di Pasar Jengkol belum ada penanganan masalah sampah pasar yang menumpuk di pinggir jalan, yang menebar bau dan pemandangan tumpukkan sampah di pinggir jalan. Dinas Perindustrian dan Perdagangan, Pemkot Tangerang Selatan mencanangkan bahwa di seluruh pasar harus ada Bank Sampah tapi sampai saat ini Pasar Jengkol juga belum memiliki Bank Sampah.

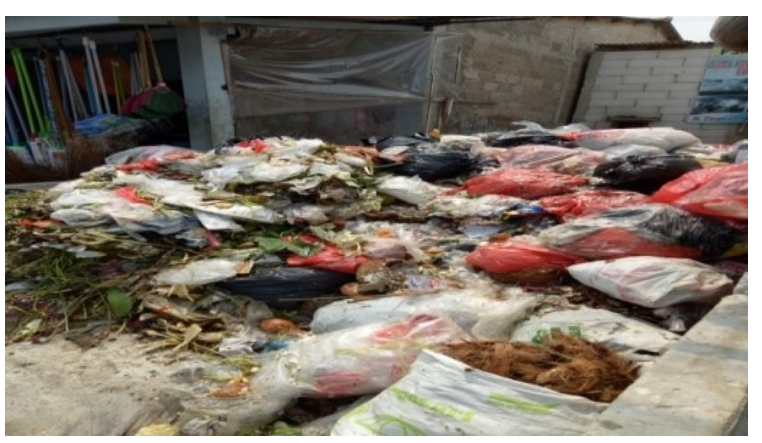

Gambar 1..TPS di pinggir jalan raya Pasar Jengkol

Tujuan kegiatan pengabdian kepada masyarakat ini adalah memberikan pendampingan pendirian Bank Sampah yang berfungsi secara efektif guna mengurangi 
tumpukkan sampah di TPS, serta menjadi mitra UPT dalam mengelola kebersihan lingkungan.Melalui kegiatan pelatihan pemilahan sampah maka sampah dikelompokan menjadi sampah anorganik dibuang ke TPA, sampah organik dibuat menjadi media tanaman dan pupuk, serta sampah daur ulang ditimbang untuk dijadikan tabungan bank sampah.

Pengelolaan Sampah Mandiri berbasis mikrobial dengan menjadikan sampah organik dari pasar sebagai produk media tanam serta budidaya tanaman bawang dayak dll. Pengelola Bank Sampah Pasar Jengkol diharapkan dapat menjadi contoh keberhasilan mengelola serta mengolah sampah sehingga memberi nilai tambah, serta menjadi Pasar Ramah Lingkungan yang terkelola secara optimal dan berkelanjutan. Manfaat kegiatan ini bagi masyarakat sekitar pasar, para pedagang yang dikoordinir oleh pengurus Bank Sampah Pasar Jengkol Resik antara lain : diharapkan jangka panjang lingkungan pasar jadi bersih, bebas polusi bau busuk sampah, sehingga kesehatan masyarakat lebih baik. Para pengelola dan para anggota bank sampah yang mengolah sampah secara mandiri secara langsung berdampak kepada berkurangnya sampah di TPS juga di TPA serta para anggota dapat nilai tambah dari hasil tabungan sampah daur ulang, hasil penjualan pupuk serta hasil penjualan tanaman hias maupun bawang dayak dll.

\section{METODOLOGI}

Berikut tahapan atau langkah-langkah dalam melaksanakan solusi yang ditawarkan untuk mengatasi permasalahan mitra Pengelola Pasar Jengkol:

1. Survei pendahuluan untuk melihat kondisi lingkungan pasar, sumber daya, fasilitas pengelolaan sampah yang ada saat ini ;

2. Koordinasi Program antara Tim Abdimas, dengan dinas indag yaitu UPT Pengelola Pasar, FORKAS, SIBAS dan pihak terkait, termasuk mitra pedagang tanaman yang berpotensi untuk kerjasama dengan Bank Sampah Organik Pasar Jengkol ;

3. Persiapan materi pelatihan dan Pendampingan ;

4. Pelaksanaan pendampingan pendirian dan Peresmian Bank Sampah ;
5. Pelaksanaan Pelatihan Pengelolahan Sampah dijadikan media tanam dengan Bio- Compound dan penataan lingkungan pasar dengan tanaman penyerap polutan yang ditanam di media sampah pasar ;

6. Evaluasi kegiatan serta koordinasi dengan UPT untuk memastikan kegiatan berkelanjutan.

\section{HASIL DAN BAHASAN}

Pendampingan Perbaikan Flow Pengelolaan Sampah

Diagram alir pengelolaan sampah merupakan langkah-langkah yang dilakukan untuk mengelola sampah-sampah yang ada pada Pasar Jengkol Diagram ini menggambarkan rangkaian pengelolaan sampah yang dimulai dari pembersihan sampah, pengangkutan sampah, pengolahan sampah berdasarkan jenisnya dan yang terakhir adalah pengangkutan sampah ke TPA terdekat. Diagram alir pengelolaan sampah ini dibuat agar petugas-petugas yang terkait dapat melakukan tugasnya sesuai dengan urutan yang telah dibuat. Berikut adalah diagram alir pengelolaan sampah ( Gambar 3.1 )

\section{Pedampingan Pendirian Bank Sampah Pasar Jengkol Resik \\ Guna keberlanjutan program} penanganan sampah pasar secara mandiri, tim juga melalui koordinasi dengan UPT Pasar yang berada dibawah Dinas Perindustrian dan Perdagangan (OPD Indag), Dinas Lingkungan Hidup (DLH) dan Silaturahmi Bank Sampah (SIBAS) Korcam Kecamatan Setu yang dihadiri Kasi Ekbang dari Kelurahan Babakan, mendirikan Bank Sampah yang diberi nama Bank Sampah Pasar Jengkol Resik. Bank Sampah ini diharapkan akan menjadi wadah bagi warga pasar dalam mendukung program penanganan sampah Kota Tangerang Selatan, khususnya sampah pasar mulai dari sumbernya,dan menjadikan sampah tersebut sebagai sumber yang memiliki nilai ekonomi 

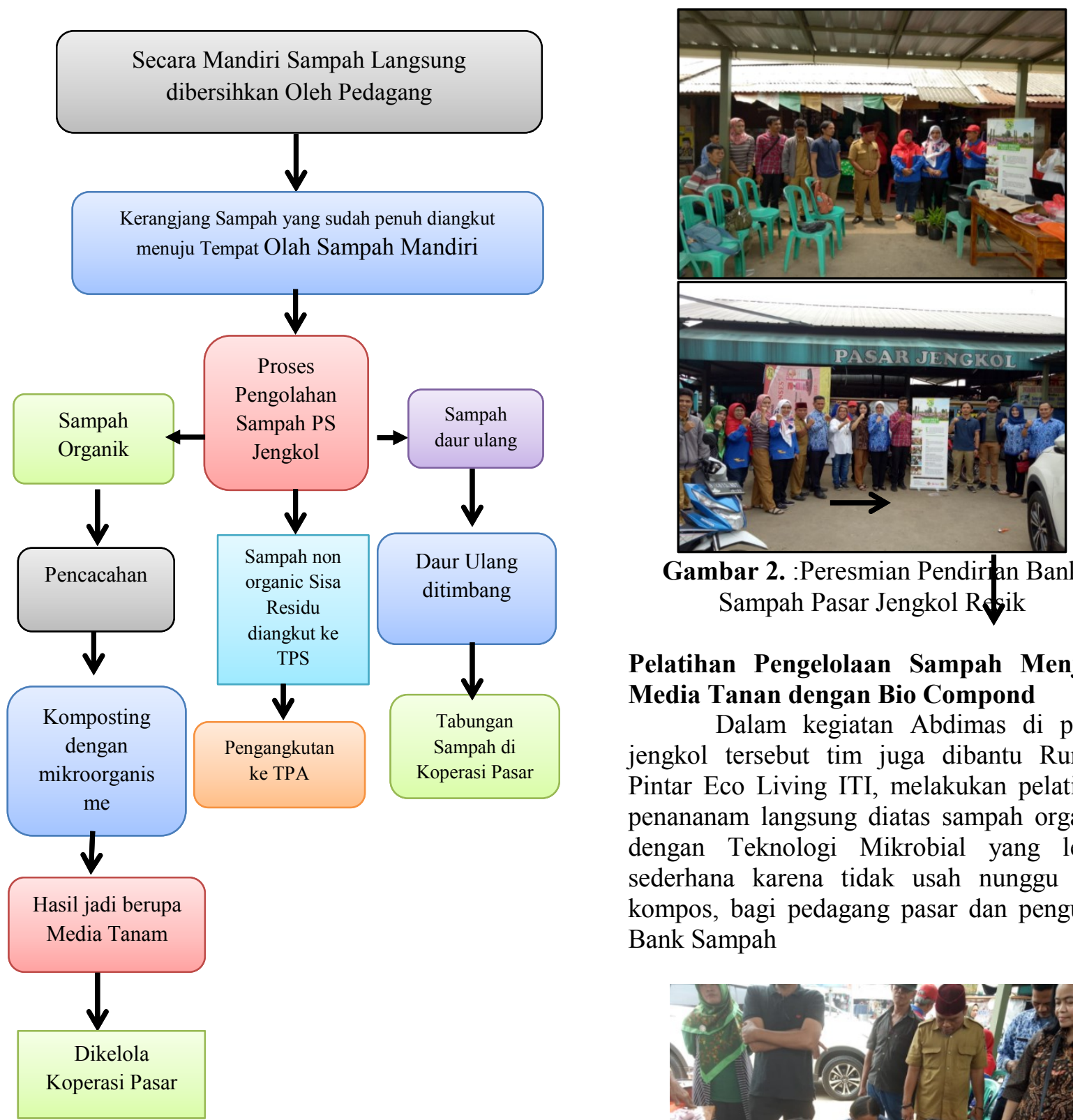

Gambar 2. :Peresmian Pendirian Bank Sampah Pasar Jengkol R sik

\section{Pelatihan Pengelolaan Sampah Menjadi Media Tanan dengan Bio Compond}

Dalam kegiatan Abdimas di pasar jengkol tersebut tim juga dibantu Rumah Pintar Eco Living ITI, melakukan pelatihan penananam langsung diatas sampah organik dengan Teknologi Mikrobial yang lebih sederhana karena tidak usah nunggu jadi kompos, bagi pedagang pasar dan pengurus Bank Sampah

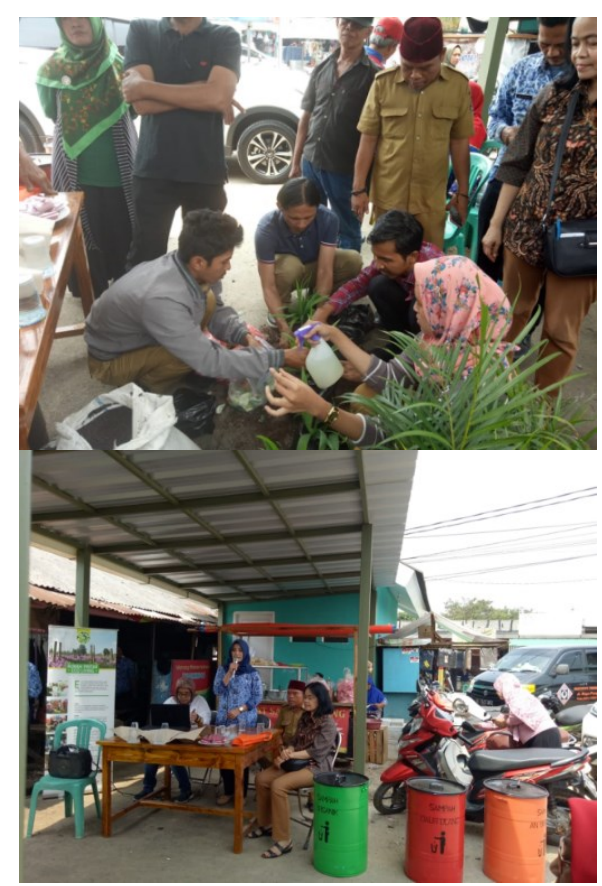

Gambar 2.3. Pelatihan penanaman pohon dengan media sampah organik 


\section{KESIMPULAN}

Program pemberdayaan masyarakat melalui pengabdian kepada masyarakat telah dapat memberikan solusi bagi sebagian permasalahan sampah yang terdapat di Pasar Jengkol. Solusi yang telah dilaksanakan antara lain yaitu:

1) Peningkatan kesadaran masyarakat ( para pedagang ) dalam memilah sampah dan menjaga kesehatan lingkungan, peningkatan kepedulian masyarakat dalam menangani sampah dan mengurangi volume sampah yang dihasilkan dari para pedagang Pasar Jengkol..

2) Masyarakat dapat ketrampilan pemilahan sampah, kemampuan teknis baru dalam melakukan daur ulang sampah, dapat memproduksi hasil berupa, media tanam dengan bantuan microbial,.

3) Terbenttuknya Bank Sampah Resik Pasar Jengkol dengan susunan pengelola sampah yang diketuai oleh Kepala Pasar Jengkol serta didampingi dan dibina oleh Dinas Lingkungan Hidup untuk kemudian berproses menjadi Bank Sampah mandiri.

\section{UCAPAN TERIMAKASIH}

Pada kesempatan ini penulis mengucapkan terimakasih kepada: (1) Lembaga Pengabdian dan Pemberdayaan Masyarakat (LP2M), Institut Teknologi Indonesia yang telah membantu dana untuk pelaksanaan kegiatan Pengabdian kepada Masyarakat, (2) Masyarakat Pasar Jengkol, Desa Rawa Kalong Kecamatan Setu, Tangerang Selatan yang telah bekerjasama dalam pelaksanaan di lapangan, (3) Dinas Lingkungan Hidup, Dinas Perindustrian dan Perdagangan, Pemkot Tangerang Selatan, SIBAS,FORKA, dan UPT Pasar Tangsel yang telah mendukung kegiatan ini, (4) Jejaring Pengelola Sampah Mandiri kecamatan Setu Tangerang Selatan.

\section{REFERENSI}

Bambang Wintoko. 2015. Panduan Praktis Mendirikan Bank Sampah. Pustaka Baru Press. Yogyakarta.

Gelbert, M. 1996. Konsep Pendidikan Lingkungan Hidup dan "Wall Chart". Buku Panduan Pendidikan Lingkungan Hidup. PPPGT/VEDC. Malang. https://news.detik.com/australiaplus/2832124 /indonesia-nomor-2-terbanyakmembuang- sampah-plastik-di-lautan.

Mundiatun dan Daryanto. 2015. Pengelolaan Kesehatan Lingkungan. Penerbit Gava Media. Yogyakarta.

Sejati, K. 2009. Pengolahan Sampah Terpadu Dengan Sistem Node, Sub Point, Center Point. Kanisius. Yogyakarta.

Setianingrum R.B. 2018. Pengelolaan sampah dengan pola 3R untuk memperoleh manfaat ekonomi bagi masyarakat. Jurnal BERDIKARI. 6 (2) :

Sormin, E. 2019 Pemberdayaan Masyarakat Melalui Pengolahan Sampah Organik Di

Desa Tempursari Kecamatan Tempursari, Kabupaten Lumajang, Jawa Timur. Jurnal Comunita Servizio. 1 (1) :11-18.

Suryati, T. 2009. Bijak dan Cerdas Mengolah Sampah. Agromedia. Jakarta.

Undang Undang Nomor 18 Tahun 2008 tentang Pengelolaan Sampah. 